\title{
DIREITO AGRÁRIO E DIREITO DE EMPRESA
}

\author{
João Alberto Schützer Del Nero \\ Professor Doutor de Direito Civil da Faculdade de Direito da \\ Universidade de São Paulo e Procurador-Chefe da Consultoria \\ Jurídica da Universidade de São Paulo
}

\begin{abstract}
Resumo:
O principal objetivo deste trabalho é distinguir o Direito Agrário, de um lado, do Direito Civil; e, de outro, do Direito Comercial lato sensu. A distinção entre o ato e a atividade permite separar-se, no sistema do Direito Privado, o Direito Civil do Direito de Empresa. O Direito Agrário, porque associado a certas atividades, não a determinados atos, é um Direito de Empresa e, portanto, não se confunde com o Direito Civil. No Direito de Empresa, encontram-se o Direito Comercial stricto sensu e o Direito Industrial, que, em seu conjunto, formam o Direito Comercial lato sensu. O Direito Agrário, porque associado a certas atividades de produção, não de circulação de bens, não se confunde com o Direito Comercial stricto sensu. Mas, para separar o Direito Agrário do Direito Industrial é preciso outra (e nova) distinção, a saber: a função desempenhada pelo "terreno" que, ou é o fator de produção "terra", no Direito Agrário; ou é apenas a base física que suporta elementos do fator de produção "capital". no Direito Industrial.
\end{abstract}

\begin{abstract}
:
The main purpose of this paper is to distinguish Agrarian Law, on the one hand, from Civil Law and, on the other, from Commercial Law in a broad sense. In Private Law system, the distinction between act and activity allows one to separate Civil Law from Enterprise Law. Because it relates with some activities, not with some acts, Agrarian Law belongs to Enterprise Law and thus differs from Civil Law. Within the Enterprise Law limits one finds Commercial Law in a narrow sense and Industrial Law, which joined up form Commercial Law in a broad sense. Because it relates with some production activities, not with distribution activities of goods, Agrarian Law differs from Commercial Law in a narrow sense. To separate Agrarian Law from Industrial Law, however, another distinction (and a new one) is needed, i.e.: the function performed by the "ground", which is either the factor of production "land" in Agrarian Law; or just physical support that bears some parts of the factor of production "capital". in Industrial Law.
\end{abstract}

Unitermos: Direito Agrário; Direito Civil; Direito de Empresa; Direito Comercial; Direito Industrial. 
Sumário:

1. Estática e dinâmica no Direito. 2. Conceito jurídico de atividade. 3. (cont.) Qualificação jurídica da atividade. 4. Atividades econômicas empresariais. 5. (cont.) Os quatro aspectos jurídicos da empresa. 6. Direito Comercial e Direito Civil: de 1850 até hoje. 7. A unidade do sistema jurídico privado obrigacional. 8. O Direito Comercial como Direito de Empresa. 9. Direito Civil e Direito de Empresa. 10. O Direito Agrário como Direito de Empresa. 11. (cont.) Aspectos doutrinários. 12. (cont.) Aspectos legislativos. 13. O Direito Agrário e o Direito de Empresa. 14. Paralelismo entre Direito Agrário e Direito Comercial. 15. "Terreno": terra (fator de produção) e base física. 16. O Direito Agrário e o Direito (Civil) das coisas. 17. Direito Civil, Direito Comercial e Direito Agrário.

\section{A. Ato e atividade no Direito Privado}

1. Estática e dinâmica no Direito. Numa sociedade em que o grau de subdivisão do trabalho é baixo, as relações interindividuais materialmente econômicas apresentam nível de complexidade igualmente baixo. A conjugação dos fatores de produção (terra, capital e trabalho) tende a concentrar-se em poucas pessoas, as mais das vezes unidas por laços de parentesco, e em poucos bens, destinando-se a produção precipuamente à subsistência do grupo; nesse contexto, as relações intersubjetivas reguladas por certas normas de conduta e de organização, isto é, normas jurídicas, que conferem àquelas o caráter de relações jurídicas, ocorrem, por assim dizer, episodicamente, sem uma permanência temporal e habitual que se possa considerar relevante, quantitativa e qualitativamente falando. As normas jurídicas, organizando a vida em sociedade e impondo condutas aos indivíduos, apresentam sentido predominantemente estático, em que ao tempo não se atribui maior importância. As relações jurídicas continuadas, que estendem temporalmente as relações intersubjetivas, não povoam o universo primitivo, onde se notam apenas figuras que se exaurem em curtos espaços de tempo.

O crescente grau de intensidade da subdivisão do trabalho, implicando maior complexidade das relações interindividuais, muda a pouco e pouco o panorama social, econômico e jurídico do grupo. A cooperação entre os diversos agentes produtivos acentua-se, objetivando, num primeiro momento, melhores condições de subsistência de certos núcleos sociais, como a família, por exemplo, e, depois, a produção de excedentes que se possam permutar; num estágio mais 
avançado de organização social, a cooperação entre os indivíduos, visando alcançar fins comuns, ultrapassa os estreitos limites dos núcleos familiares, fundando-se em laços diversos dos vínculos de parentesco. É essa cooperação que vai atribuir às relações jurídicas caráter dinâmico, continuado, em que o tempo e as mudanças de algumas condições e a permanência de outras, nele possíveis, adquirem maior relevância jurídica.

A ordem jurídica primitiva, predominantemente estática, cujo cerne eram atos episódicos e momentâneos e relações intersubjetivas de curta duração, alarga-se, devendo agora cuidar de conjuntos de atos que guardam entre si uma certa correlação, na medida em que praticados por indivíduos que agem em cooperação na busca de fins comuns e mantêm entre si relações continuadas, ou seja, à ordem jurídica se acrescenta um sentido dinâmico, em que atos, indivíduos e relações podem - e devem - ser encarados como entes dotados de permanência temporal.

Se, estaticamente, a figura central da ordem jurídica é o ato, dinamicamente o é a atividade. Atividade entendida como conjunto de atos coordenados ou unificados, no plano funcional, pela unidade do escopo. ${ }^{1} \mathrm{O}$ conceito de atividade ostenta notável eficácia instrumental para a compreensão dos reflexos jurídicos de três importantes fenômenos: a. o problema da qualificação jurídica dos comerciantes italianos na Idade Média, em virtude da necessidade de fixação dos limites da jurisdição (especial) comercial; b. a Revolução Industrial do século XIX e as questões do conflito entre trabalho e capital e da passagem da indústria artesanal para a indústria de massa; e c. a expansão dos serviços públicos e as transformações do Estado contemporâneo, em que a administração pública se entende não mais como apenas exercício de um poder, mas também como prestação de serviços (públicos), além de se conceber o Estado como produtor e executor de políticas ou ações, isto é, atividades planejadas — e não-somente de normas jurídicas. ${ }^{2}$

2. Conceito jurídico de atividade. A atividade, como facti species de eficácia (talvez seja melhor falar de incidência, e não de eficácia) jurídica, ${ }^{3}$ é um

1. Giuseppe Auletta - "Attività (Dir. Priv.)", verbete in Enciclopedia del Diritto, v. III, Milano, Dott. A. Giuffrè - Editore, 1958, pp. 981-987, especialmente p. 982.

2. Fábio Konder Comparato - "Anotações de aula" Curso de pós-graduação da Faculdade de Direito da Universidade de São Paulo - Ato e atividade no Direito Privado contemporâneo --, ministrado com Antonio Junqueira de Azevedo; São Paulo, $1^{\circ}$ semestre de 1988.

3. Giuseppe Auletta, ob. cit., p. 982. 
conjunto de atos imputados a um mesmo centro de interesses, praticados durante um certo período de tempo, tendo em vista a realização de um determinado objetivo, e submetidos a um mesmo regime jurídico.

A atividade não é situação estática (status), nem estado de fato (como a posse, por exemplo) ou de fruição (como a locação, por exemplo): a atividade é eminentemente dinâmica, concorrendo para a realização do objetivo, e não apenas decorrendo de uma finalidade preestabelecida. No que respeita ao conjunto de atos, cumpre salientar que nele se inserem atos jurídicos, até mesmo negócios jurídicos, e atos não-jurídicos. A imputação a centros de interesses, e não apenas a pessoas físicas ou jurídicas, resulta de se reconhecer a existência de universalidades não personificadas (como o espólio e a massa falida, por exemplo), tratadas como centros de feixes de relações jurídicas. Quanto à temporalidade, digamos que a atividade deve apresentar um sentido de permanência, de duração: não há mister seja indefinida, porém não se a vê surgir na eventualidade. A atividade é instrumental, visto que a coordenação funcional dos atos só aparece em virtude do objetivo a ser alcançado (perdido o objetivo, a atividade torna-se agitação); daí uma lógica de meio-e-fim na organização da atividade, precipuamente finalista, em que as regras são postas pelo empresário (atividade autônoma) ou por outrem (atividade heterônoma). ${ }^{4}$

3. (cont.) Qualificação jurídica da atividade. O problema da qualificação jurídica da atividade (jurídica) não apresenta resposta definitiva. Fábio Konder Comparato sugere uma qualificação jurídica para a atividade que parece bastante útil: para ele, ao lado das universalidades de pessoas e das universalidades de bens, haveria as universalidades de atos; e a atividade seria precisamente uma universalidade de atos. A atividade jurídica seria uma universalidade de atos, regida pelo princípio - comum a toda universalidade - de que a existência do todo é independente da existência das partes. ${ }^{5}$

É justamente por força dessa independência entre o todo e as partes, na universalidade, que se pode compreender a diversidade entre o regime jurídico da atividade e o regime jurídico de cada um dos atos que a integram. Assim, as questões sobre a existência, a validade e a eficácia dos atos jurídicos não se apresentarão da

\footnotetext{
4. Fábio Konder Comparato, ibidem.

5. Idem, ibidem.
} 
mesma maneira no que concerne à atividade: a atividade existe ou não existe; existindo, é regular ou irregular, lícita ou ilícita, mas não-válida ou inválida, nula ou anulável; pode ser aparente, mas não simulada; em geral, a eficácia da atividade se produz independentemente da vontade de seu autor (por exemplo, o status de comerciante). A capacidade e a legitimidade também recebem tratamentos jurídicos diversos: no que concerne à atividade, não há falar em capacidade absoluta e em capacidade relativa, mas em capacidade tout court, que existe ou não-existe; demais, as incapacidades para os atos são concebidas em favor do incapaz, ao passo que as incapacidades para a atividade se criam para proteger o público. No que respeita à publicidade e à representação, atos e atividades também recebem tratamentos jurídicos diferentes. ${ }^{6}$

4. Atividades econômicas empresariais. Dentre as diversas classificações das atividades, a que conduz à identificação das atividades econômicas empresariais tem especial relevância para este trabalho. Vejamo-la.

As atividades de produção ou de circulação de bens ou serviços pecuniariamente apreciáveis, isto é, as que tendem à criação de riquezas -utilidades ou valores econômicos — são chamadas atividades econômicas. Nelas, como facti species de incidência jurídica, sobressai o requisito da profissionalidade, decorrente de avaliação social associada a uma certa duração ou permanência temporal da atividade, que, embora não necessariamente contínua e indefinida, deve ser não-ocasional; constante, ainda que periódica. As atividades profissionais subdividem-se em: a. atividades do trabalhador autônomo; b. atividades do profissional liberal; e c. atividades do empresário - e aqui surgem as atividades que mais de perto nos interessam: as atividades econômicas empresariais. ${ }^{7}$

5. (cont.) Os quatro aspectos jurídicos da empresa. Neste ponto começa a se delinear questão tormentosa para a teoria do Direito: o conceito de empresa e sua correlação com os conceitos de empresário, de atividade empresarial e de estabelecimento. Não é objetivo deste trabalho aprofundar a discussão sobre o

6. Idem, ibidem. Ver também Giuseppe Auletta, ob. cit,, pp. 985-987. Outro aspecto em que ato e atividade se submetem a princípios diversos parece ser o da responsabilidade civil; talvez daí, pelo menos em parte, a dificuldade que o Direito Civil enfrenta ao cuidar das chamadas responsabilidades objetivas ou sem culpa.

7. Giuseppe Auletta, ob. cit., p. 982. 
tema, mas algumas considerações se impõem. Parece difícil alcançar um conceito jurídico único de empresa, sendo talvez mais apropriado falar de aspectos ou perfis (que não deixam de ser conceitos) jurídicos do conceito econômico de empresa: $1^{\circ}$ em sentido subjetivo, como expressão sinônima de empresário, substituindo-se, por metonímia, o agente pela atividade por ele exercida; $2^{\circ}$. em sentido funcional, como atividade empresarial dirigida a certo objetivo; $3^{\circ}$. em sentido objetivo e patrimonial, como complexo de bens organizado pelo empresário para o exercício da atividade empresarial (estabelecimento); e $4^{\circ}$. em sentido corporativo, como instituição decorrente de uma organização de pessoas, formada pelo empresário, pelos prestadores de trabalho e seus colaboradores, visando a um objetivo econômico comum. $^{8}$

Empresário, por sua vez, é quem exerce, profissionalmente, uma atividade econômica organizada para a produção de bens ou serviços; ${ }^{9}$ são, portanto, elementos do conceito de empresário: a. o exercício de atividade econômica, destinada à criação ou circulação de riquezas; b. a atividade organizada mediante adequada coordenação dos fatores de produção (terra, capital, trabalho e tecnologia); e c. o exercício praticado de modo profissional, isto é, habitual e sistemático. ${ }^{10}$

Ora, falar em atividade econômica organizada pressupõe um complexo de bens destinado a um objetivo de produção ou de circulação: atividade empresarial e estabelecimento são, portanto, noções complementares. ${ }^{11} \mathrm{E}$ mais: a atividade econômica organizada pressupõe alguém que a exerça, profissionalmente, isto é, a figura do empresário está implícita nas duas noções, surgindo, portanto, uma dialética de implicação e polaridade entre estes três termos: empresário, atividade e estabelecimento.

8. Alberto Asquini - "Profili dell'impresa", in Rivista del Diritto Commerciale, v. 4l, I parte, Milano, 1943, pp. 1-2; citado por Oscar Barreto Filho - Teoria do estabelecimento comercial, São Paulo, Max Limonad, 1969, pp. 25-26.

9. Fábio Konder Comparato - $O$ poder de controle na sociedade anônima, $3^{\mathbf{a}}$ edição, inteiramente revista, atualizada e corrigida, Rio de Janeiro, Ed. Forense, 1983, p. 94.

10. Oscar Barreto Filho, ob. cit., p. 112.

11. Idem, ibidem, p. 132. Ver também Fábio Konder Comparato, O poder de controle na sociedade anônima, cit., p. 94. 
B. Atividade mercantil: o Direito Comercial como Direito de Empresa

6. Direito Comercial e Direito Civil: de 1850 até hoje. No Direito brasileiro encontramos duplicidade de normas jurídicas legislativas que regem determinadas obrigações privadas. No que concerne a certas espécies obrigacionais, tais como, por exemplo, compra-e-venda, mandato, depósito e mútuo, incidem, conforme o caso, ora normas do Código Civil, ora do Código Comercial; a incidência de umas ou de outras depende de circunstâncias que exigem a identificação de obrigações civis ou de obrigações mercantis. Surge, assim, preliminarmente um problema de qualificação jurídica, que antecede $\mathrm{o}$ reconhecimento da incidência e aplicação das normas legais. A qualificação jurídica decorre da avaliação de uma situação de fato perante a ordem jurídica, ou, melhor, de sua identificação com o modelo ou tipo descrito na hipótese de incidência da norma jurídica. Esse problema de qualificação jurídica surge, na teoria do Direito Comercial tradicional, como delimitação da chamada "matéria de comércio" a que se associa a discussão sobre a autonomia do Direito Comercial no campo do Direito Privado. ${ }^{12}$

O interesse prático na delimitação da chamada matéria de comércio, funcionalmente falando, prendia-se, nos idos de 1850, a duas razões: além do problema da qualificação jurídica, havia a questão da determinação da competência judiciária, decorrente da existência de uma jurisdição mercantil, configurada pelos Tribunais de Comércio (órgãos jurisdicionais de primeiro grau). Esses Tribunais de Comércio eram competentes para julgar as "causas comerciais" reputando-se tais "todas as causas que derivarem de direitos e obrigações sujeitas às disposições do Código Comercial, contanto que uma das partes seja comerciante". (art. 18); além disso, seriam também julgadas na conformidade das disposições do Código Comercial, e pela mesma forma de procedimento, "ainda que não intervenha pessoa comerciante: 1. as questões entre particulares sobre títulos da divida pública, $e$ outro quaisquer papéis de crédito do Governo; 2. as questões de companhias ou sociedades, qualquer que seja a sua natureza ou objeto; 3 . as questões que derivarem de contratos de locação compreendidos nas disposições do Título $X$ do Código Comercial, com exceção somente das que forem relativas à locação de

12. Ver Fábio Konder Comparato - Novos ensaios e pareceres de direito empresarial, Rio de Janeiro, Ed. Forense, 1981, p. 246. 
prédios rústicos ou urbanos" (art. 19). O Decreto n. 737, de 25 de novembro de 1850 , exorbitando de sua função puramente regulamentar, acrescentou ao rol das causas a ser julgadas pelos juízes do comércio, mesmo entre partes nãocomerciantes, "as questões relativas a letras de câmbio e de terra, seguros, riscos e fretamentos" $\left(\operatorname{art} .20, \S 4^{\circ}\right){ }^{13}$

Em 1875 unificou-se no Brasil a Justiça Cível, revogando-se o Título Único do Código Comercial e suprimindo-se, portanto, os Tribunais de Comércio. Assim, embora vigente o Decreto n. 737, como estatuto processual, desapareceu o motivo da determinação da competência judiciária como relevante para a delimitação da matéria de comércio, perdendo seu sentido a discussão sobre os atos de comércio, como categoria genérica. O problema das fronteiras entre o Direito Comercial e o Direito Civil reduziu-se, portanto, a duas questões: $1^{\mathrm{a}}$ a definição da mercancia, como atividade profissional do comerciante necessária para a aquisição dessa qualidade independentemente da matrícula nos Tribunais de Comércio (Código Comercial, art. $4^{\circ}$ ); além disso, o conceito estender-se-ia à matéria societária, distinguindo-se, segundo a natureza do objeto social, as sociedades mercantis das sociedades civis; e $2^{\mathrm{a}}$ a distinção entre obrigações e contratos mercantis, de um lado, e obrigações e contratos civis, de outro. As normas de Direito Cambial, pela ausência de duplicidade legislativa, não implicavam nenhum problema de qualificação jurídica. ${ }^{14}$

7. A unidade do sistema jurídico privado obrigacional. Nesta altura, é importante salientar o que exatamente há de contato e de afastamento entre o Direito Civil e o Direito Comercial, permitindo considerar-se ambos integrantes de um só sistema obrigacional. Di-lo, precisa e sinteticamente, Fábio Konder Comparato:

Delimitados, assim, os campos respectivos do Direito Comercial e do Civil, em matéria obrigacional, importa assinalar que, no próprio regime do Código Comercial, o princípio é a aplicação das normas civis, figurando os dispositivos do Código de Comércio como autênticas normas de exceção - não no sentido de restrição ao direito, mas de

13. Idem, ibidem, pp. 247-248.

14. Idem, ibidem, pp. 249-250. 
aplicação especial a casos determinados. $O$ art. 121 declara que "as regras e disposições do Direito Civil para os contratos em geral são aplicáveis aos contratos comerciais, com as modificações e restrições estabelecidas neste Código" E o art. 428, paralelamente, dispõe que "as obrigações comerciais dissolvem-se por todos os meios que o Direito Civil admite para a extinção e dissolução das obrigações em geral, com as modificações deste Código". Temos, pois, que não há, propriamente, contraposição de dois sistemas jurídicos distintos, em matéria de obrigações: o do Código Civil e o do Código Comercial. O que há é um só sistema, no qual os dispositivos do Código de Comércio aparecem como modificações específicas das regras gerais da legislação civil, relativamente às obrigações e contratos mercantis. A duplicidade aparece, tão-só, no que tange a essas regras de excę̧ão, dentro do sistema global. ${ }^{15}$

8. O Direito Comercial como Direito de Empresa. Historicamente, o Direito Comercial surge como estatuto dos comerciantes, entendidos como pessoas que adquirem bens (mercadorias) a umas, a fim de revendê-las a outras, objetivando auferir lucro com as operações; a prática reiterada e constante dessas operações configura o exercício de uma profissão para os que a realizam habitualmente - os comerciantes -, caracterizada pela intermediação entre produtores e consumidores e pelo objetivo de lucro, implícito na compra para revenda. Bem que principal, a compra para revenda não era a única operação realizada pelos comerciantes: outros atos acessórios também passaram a ser praticados, tais como o transporte, o depósito, o penhor de mercadorias e o mandato; além disso, figuras inicialmente ligadas ao exercício do comércio e, portanto, incluídas no Direito Comercial, tais como os títulos cambiários, introduziram-se na vida quotidiana de outras pessoas não-comerciantes, embora nele permanecessem. Assim, a definição do Direito Comercial como direito dos comerciantes (Direito Comercial subjetivo) deixa de abranger todo o definido, tornando-se insatisfatória. ${ }^{16}$

15. Ibidem, p. 251.

16. Fran Martins - Curso de direito comercial: empresa comercial, empresários individuais, sociedades comerciais, fundo de comércio, $11^{3}$ edição, revista e atualizada, Rio de Janeiro, Ed Forense, 1986, pp. 25-27. 
O Código de Comércio francês, de 1807 (em vigor a partir de 1808), dispõe em seu art. $1^{\circ}$ que "são comerciantes os que exercem atos de comércio e deles fazem profissão habitual". enumerando no art. 632 os atos que, por sua natureza, caracterizam a profissão comercial e, no art. 633, os que eram considerados comerciais mesmo que praticados não-profissionalmente, isto é, mesmo que praticados por não-comerciantes. O Direito Comercial passa, então, a se referir a atos de comércio (Direito Comercial objetivo). ${ }^{17}$ Mas essas enumerações taxativas acarretam graves problemas de qualificação, visto que a realidade constantemente alarga seus horizontes e apresenta nuanças, impossibilitando sua coordenação a tipos ou modelos limitados e rígidos, estabelecidos de antemão.

Daí a recente tendência de considerar o Direito Comercial como Direito de Empresa, ou, nas palavras de Fábio Konder Comparato: "O conceito básico do moderno Direito Comercial é o de atividade empresarial, substituindo a velha noção de ato de comércio" 18

Já se salientou o desdobramento jurídico do conceito (econômico) de empresa, em seus vários aspectos: o empresário, a atividade empresarial, o estabelecimento e a corporação; ${ }^{19}$ assim, o Direito de Empresa é o regime jurídico da atividade empresarial, dela sendo sujeito o empresário, e objeto o estabelecimento empresarial. Ora, sendo assim, não procede a crítica, tantas vezes repetida, de que o conceito de empresa é puramente econômico, e não-jurídico, sendo, portanto, de duvidosa utilidade para o Direito: em primeiro lugar porque ao Direito não são estranhos conceitos técnicos originariamente não-legislativos, mas funcionalmente jurídicos (a morte, por exemplo, cuja noção é essencial à tipificação do crime de homicídio, não ostenta definição legislativa); em segundo lugar porque, se houver definição legislativa de qualquer um dos três termos que se implicam e polarizam dialeticamente (o empresário, a atividade empresarial e o estabelecimento empresarial), o conceito jurídico de empresa, bem que não imediatamente legislativo, mediatamente o será, visto serem eles aspectos de um mesmo fenômeno. ${ }^{20}$

17. Idem, ibidem, p. 27.

18. O poder de controle na sociedade anônima, cit., p. 93.

19. Ver supra, n. 5.

20. Ver supra, n. 5. 
9. Direito Civil e Direito de Empresa. Voltemos agora ao problema do sistema jurídico do Direito Privado. Como bem adverte Pontes de Miranda:

\section{[...] as linhas discretivas entre Direito Civil e} Direito Comercial se foram apagando, até que a Parte Geral do Direito privado não mais tolerou a dicotomia que artificialmente - mercê de reminiscências históricas, ligadas a classes - se the havia imposto. O próprio critério do valor de uso, que interessaria, especificamente, ao direito civil, e valor de câmbio, de troca, que caracterizaria o Direito Comercial, ou, respectivamente, riquezas formadas e riquezas in fieri, acabou por mostrar que só traduzia preponderância de critério. A falta de sistematização unitária do direito privado foi causa de surgirem ramos de Direito, correspondentes a necessidades novas, entre o Direito Civil e o Direito Comercial, ou nas fronteiras dele com o Direito Público, para os quais não bastavam os meios da dicotomia tradicional (Direito do Trabalho, Direito Industrial). ${ }^{21}$

Ora, se a grande dicotomia, no campo do Direito Privado, se faz a partir da distinção entre ato e atividade (empresarial), teremos lado a lado um Direito Civil e um Direito de Empresa, ambos integrando um só sistema -- o sistema do Direito Privado. E, parafraseando Konder Comparato, ${ }^{22}$ poderíamos dizer que o Direito de Empresa consiste no grupo de normas de incidência e aplicação excepcional (especial e específica para certos casos), no concernente a obrigações e contratos de empresa e, eventualmente, ao chamado Direito das Coisas. ${ }^{23}$

21. Francisco Cavalcanti Pontes de Miranda - Tratado de direito privado, tomo XV, $4^{\mathbf{a}}$ ed., São Paulo, Editora Revista dos Tribunais, 1977, pp. 358-359.

22. Ver supra, n. 7.

23. O Direito do Trabalho também poderia ser entendido como um direito de exceção ao Direito Civil, especialmente no que respeita ao contrato de locação de serviços; nesse sentido, pertenceria igualmente ao sistema jurídico do Direito Privado. Não-obstante os esforços doutrinários para incluí-lo no Direito Público, quiçá em decorrência do caráter eminentemente tutelar de suas normas, parece-me melhor situado no Direito Privado. Cumpre não-confundir as chamadas normas de ordem pública ou normas jurídicas cogentes com o Direito Público; nem as normas dispositivas (quer integrativas, quer interpretativas) com o Direito Privado: há normas de ordem pública tanto no Direito Público quanto no Direito Privado, e há normas dispositivas tanto no Direito Privado quanto no Direito Público, talvez apenas com ocorrências quantitativamente diferentes. 
Sendo assim, ao Direito de Empresa corresponderiam as atividades empresariais de produção ou de circulação de bens ou serviços. Tendo em vista a própria atividade empresarial, especificamente no tocante ao seu objetivo, o Direito de Empresa admitiria a seguinte subdivisão: a. Direito Comercial ou Mercantil em sentido estrito, se a atividade empresarial se destinasse à circulação de bens ou serviços; e b. Direito Industrial (que pertence tradicionalmente ao Direito Comercial ou Mercantil em sentido amplo), se a atividade empresarial visasse à produção de bens ou serviços. Conviria, juridicamente falando, alguma outra subdivisão?

\section{O Direito Agrário como Direito de Empresa}

10. Não há classificações verdadeiras ou falsas, certas ou erradas; há, sim, classificações mais úteis ou menos úteis, na medida de sua aptidão para indicar especificidades. Por outras palavras e restringindo a questão ao âmbito do Direito, as distinções político-jurídicas são úteis se apontam ao legislador razões suficientes para a positivação de um regime jurídico especial e específico; e as distinções técnico-jurídicas são úteis se são capazes de identificar regimes jurídicos especiais e específicos diversos, já positivados, bem como apontar as razões da diversidade. ${ }^{24}$

A questão fundamental em que ora nos ocupamos é a de localizar o assim chamado "Direito Agrário" no quadro atrás delineado.

Parece evidente que um Direito Agrário deveria se vincular a idéias porventura presentes nas expressões "agricultura" "agrícola" "rural"; mas em que sentido se faria alguma ligação entre essas noções? Partindo do uso comum dessas expressões, talvez seja possível ver-se na idéia comum de agricultura um certo tipo de atividade: o cultivo do campo, da terra; na de agrícola, o adjetivo que qualifica um certo resultado: o resultado do cultivo do campo, da terra, isto é, o adjetivo que acompanha, especificando, o produto obtido com a atividade chamada "agricultura"; e na de rural, um outro adjetivo qualificativo, que acompanha, especificando, o lugar onde normalmente se desenvolve a atividade chamada agricultura e se obtêm os chamados "produtos agrícolas" Seja como for, uma primeira conclusão parece

24. As distinções técnico-jurídicas são fundamentais para a aplicação do Direito, especialmente no que concerne às diferenças entre a analogia e a interpretação extensiva, relevante sobretudo nos sistemas de tipicidade fechada. 
impor-se: estamos lidando com algo que se insere no campo das atividades, e não no dos atos.

Sendo assim, um Direito Agrário não incluído no campo do Direito Público $^{25}$ surgiria, no sistema jurídico do Direito Privado, como um Direito de Empresa, e não no tradicionalmente chamado Direito Civil. Mas então nosso problema de individualização do Direito Agrário se teria apenas adiado, visto que, estremado do Direito Civil, seria tão-somente parte do Direito Comercial ou Mercantil em sentido amplo. ${ }^{26}$ Essa conclusão parece indicar que estamos no caminho certo, visto que os "comercialistas" sempre dispensaram muito maior atenção ao Direito Agrário que os "civilistas"

Voltando à nossa questão principal, caberia indagar se, do ponto de vista técnico-jurídico - e, eventualmente, da perspectiva político-jurídica —, é útil e necessária uma distinção entre o Direito Agrário e o Direito Comercial ou Mercantil em sentido amplo, ambos, conforme salientado, direitos de empresa.

No que concerne ao resultado propriamente dito do exercício da atividade empresarial destinada à produção de bens ou serviços, poderíamos subdividi-las, segundo a finalidade dos produtos: a. produtos para a alimentação, a identificar o Direito Agrário; e b. outros produtos, a identificar o Direito Comercial ou Mercantil lato sensu. Tenho para mim que semelhante distinção seria de utilidade duvidosa, em primeiro lugar, porque formulada negativamente: os "outros produtos". seriam os não-alimentícios (mas quais seriam os alimentícios?); em segundo lugar, porque nem todos os produtos agrícolas satisfazem necessidades alimentares, bastando lembrar, por exemplo, os destinados ao vestuário; em terceiro lugar, porque alimentos artificiais haveriam de ser considerados produtos agrícolas (?!), e não produtos industriais; em quarto lugar, porque, se a razão da distinção diz com a relevância e a indispensabilidade dos produtos alimentícios para a subsistência do ser humano, outros produtos - como, por exemplo, certos remédios, obtidos pela indústria farmacêutica — também deveriam ser considerados agrícolas (?!); e, em quinto e último lugar, porque esse não é o critério que se infere das ordens jurídicas, assim passadas como presentes.

25. Embora não possa aprofundar o tema, ressalto que numa ordem jurídica em que se reconheçarn e garantam a propriedade privada dos bens de produção, a liberdade de iniciativa e a livreconcorrência, e em que haja intervencionismo econômico, mas não dirigismo econômico, o Direito Agrário estará no campo do Direito Privado, e não no do Direito Público.

26. Ver supra, n. 9. 
11. (cont.) Aspectos doutrinários. Antes de aprofundar nossa busca de uma distinção entre o Direito Agrário e o Direito Comercial ou Mercantil em sentido amplo, parece importante ressaltar ainda mais os pontos de contato entre eles, que indicam, sobretudo, serem ambos direitos de empresa. Voltaremos depois a indagar sobre uma eventual distinção entre um e outro.

No âmbito da doutrina, vejamos, a título exemplificativo e ilustrativo, duas concepções interessantes. É de Fran Martins a seguinte afirmação:

Mesmo no que se refere aos atos praticados pelos comerciantes no exercício de sua profissão, a tradição conserva fora do âmbito do direito comercial os atos relativos aos imóveis e à indústria agrícola. Os primeiros estão afastados do campo do direito comercial porque, tendo este como uma das suas características a circulação dos bens, tal não acontece com os imóveis, por sua natureza inamovíveis. Na verdade, em essência, o argumento não tem solidez, pois, para que os bens passem de propriedade, não é necessário que sejam removidos materialmente; nas Bolsas de Mercadorias faz-se a circulação dos bens apenas pela mudança de propriedade dos títulos representativos dos mesmos, e essas operações são reputadas comerciais. Ademais, os imóveis podem ser e são objeto de especulação e deveriam, desse modo, entrar essas operações no âmbito do direito comercial e não do civil. Quanto às atividades agrícolas, a razão de sua separação do terreno do direito comercial reside no fato de não ser o agricultor um intermediário e sim um produtor. Igualmente, aqui não se justifica a separação, pois o agricultor que planta, colhe e vende os seus produtos está, na realidade, praticando uma operação especulativa, e o faz profissionalmente. $^{27}$

27. Curso de Direito Comercial: empresa comercial, empresários individuais, sociedades comerciais, fundo de comércio, cit., pp. 84-85. 
Pontes de Miranda, tratando da conceituação de empresa e de fundo de empresa, diz:

Ao complexo de bens que se destina ao exercício do empreendimento, se comercial, chama-se fundo de comércio, termo que se estendeu a qualquer fundo, industrial ou agrícola, com prejuizo para a terminologia científica. Fundo de empresa diz melhor e mais acertadamente. ${ }^{28}$

$[\ldots]$

A camada de bens, imóveis ou móveis, corpóreos ou incorpóreos, que serve à organização destinada a fins nãoeconômicos ou somente de consumo, é - sem dúvida - fundo, porém não fundo de empresa, no sentido estrito de que aqui cogitamos. Seria erro, todavia, pormos fora do conceito os fundos agrários e de artesãos, ou dos profissionais de qualquer ramo, se econômica a atividade e econômico o fim, ou qualquer fundo que seja dependente da pessoa física que o tem; ${ }^{29}$

$[\ldots]$

A noção de fundo de empresa, originariamente "fundo de comércio" porque não se haviam caracterizado a situações idênticas na indústria e na agricultura; ${ }^{30}$ $[\ldots]$

A coligação dos elementos que compõem o fundo de empresa não podia deixar de interessar ao direito. A princípio, só se prestou atenção à atividade comercial, tanto mais quanto as indústrias e agricultura, como as atividades profissionais, se exerciam dentro de quadros que não permitiam se desse toda a importância à iniciativa e à atividade dos empreendedores. ${ }^{31}$

28. Tratado de Direito Privado, cit., tomo XV, p. 355.

29. Ibidem, p. 356.

30. Ibidem, p. 359.

31. Ibidem, p. 366. 
12. (Cont.) Aspectos legislativos. Vê-se, então, que à doutrina não é estranho o tratamento conjunto de atividades, empresas, empresários e estabelecimentos (ou fundos) comerciais, industriais e agrícolas. $\mathrm{Na}$ nossa legislação, bem que se não possa falar indiscriminadamente de um tratamento único e igual, as referências também apontam uma certa associação, cujo denominador comum parece ser a atividade ou a empresa, esta em seus vários aspectos jurídicos. Vejamos, novamente a título exemplificativo e ilustrativo, algumas delas.

O Código Civil, em seu art. 112 , dispõe (grifos meus):

Presumem-se, porém, de boa-fé e valem, os negócios ordinários indispensáveis à manutenção do estabelecimento mercantil, agrícola, ou industrial do devedor.

No Estatuto da Terra (Lei n. 4.504, de 30 de novembro de 1964), vamos encontral em várias passagens as expressões "empresa" "empresário" "atividade" (muitas vezes substituída por "exploração") e "estabelecimento" bem que a mais freqüente seja "atividade" Por exemplo (grifos meus):

"Empresa rural" é o empreendimento de pessoa física ou jurídica, pública ou privada, que explore econômica $e$ racionalmente imóvel rural, dentro de condição de rendimento econômico [...] da região em que se situe e que explore área mínima agricultável do imóvel segundo padrões fixados, pública e previamente, pelo Poder Executivo (art. $\left.4^{\circ}, \mathrm{VI}\right)$;

Na determinação, para efeitos do Imposto de Renda, do rendimento líquido da exploração agrícola ou pastoril, das indústrias extrativas, vegetal e animal, e da transformação de produtos agrícolas e pecuários feita pelo próprio agricultor ou criador, com matéria-prima da propriedade explorada, [...] (art. 53 , caput);

[...] a criação do espírito empresarial e a formação adequada em economia doméstica, indispensável à gerência dos 
pequenos estabelecimentos rurais e à administração da própria vida familiar (art. 75, $\S 4^{\circ}$ "c");

A posse ou uso temporário da terra serão exercidos em virtude de contrato expresso ou tácito, estabelecido entre o proprietário e os que nela exercem atividade agrícola ou pecuária, sob forma de arrendamento rural, de parceria agrícola, pecuária, agroindustrial e extrativa, nos termos desta Lei (art. 92, caput).

Na Constituição da República encontramos as seguintes referências (grifos meus):

A pequena propriedade rural, assim definida em lei, desde que trabalhada pela família, não será objeto de penhora para pagamento de débitos decorrentes de sua atividade produtiva, [...] (art. $5^{\circ}, \mathrm{XXVI)}$;

São direito dos trabalhadores urbanos e rurais, além de outros que visem à melhoria de sua condição social: [...] participação nos lucros, ou resultados, desvinculada da remuneração, e, excepcionalmente, participação na gestão da empresa, conforme definido em lei (art. $\left.7^{\circ}, \mathrm{XI}\right)$;

O imposto previsto no inciso VI terá suas alíquotas fixadas de forma a desestimular a manutenção de propriedades improdutivas e não incidirá sobre pequenas glebas rurais, definidas em lei, quando as explore, só ou com sua família, o proprietário que não possua outro imóvel (art. 153, § $4^{\circ}$ );

São insuscetíveis de desapropriação para fins de reforma agrária: ... a propriedade produtiva. A lei garantirá tratamento especial à propriedade produtiva e fixará normas para o cumprimento dos requisitos relativos à sua função social (art. 185, II, e parágrafo único.); 
A função social é cumprida quando a propriedade rural atende, simultaneamente, segundo critérios e graus de exigência estabelecidos em lei, aos seguintes requisitos: [...] exploração que favoreça o bem-estar dos proprietários e dos trabalhadores (art. 186, IV);

Incluem-se no planejamento agrícola as atividades agroindustriais, agropecuárias, pesqueiras e florestais (art. 187, § $1^{\circ}$;

Aquele que, não sendo proprietário de imóvel rural ou urbano, possua como seu, por cinco anos ininterruptos, sem oposição, área de terra, em zona rural, não superior a cinqüenta hectares, tornando-a produtiva por seu trabalho ou de sua família, tendo nela sua moradia, adquirir-lhe-á a propriedade (art. 191, caput);

O produtor, o parceiro, o meeiro e o arrendatário rurais, o garimpeiro e o pescador artesanal, bem como os seus respectivos cônjuges, que exerçam suas atividades em regime de economia familiar, sem empregados permanentes, contribuirão para a seguridade social mediante a aplicação de uma alíquota sobre o resultado da comercialização da produção e farão jus aos benefícios nos termos da lei (art. 195, $\S 8^{\circ}$ );

A lei criará o Serviço Nacional de Aprendizagem Rural (Senar) nos moldes da legislação relativa ao Serviço Nacional de Aprendizagem Industrial (Senai) e ao Serviço Nacional de Aprendizagem do Comércio (Senac), [...] (art. 62 do Ato das Disposições Constitucionais Transitórias).

O Projeto de Código Civil (n. 634-B/75), no Livro II - Do Direito de Empresa, apresenta dispositivos de grande interesse (grifos meus): 
Considera-se empresário quem exerce profissionalmente atividade econômica organizada para a produção ou a circulação de bens ou de serviços (art. 969, caput);

São dispensados de inscrição e das restrições e deveres impostos aos empresários inscritos: I - O empresário rural, assim considerado o que exerce atividade destinada à produção agrícola, silvícola, pecuária e outras conexas, como a que tenha por finalidade transformar ou alienar os respectivos produtos, quando pertinentes aos serviços rurais (art. 973, I);

O empresário, cuja atividade rural constitua sua principal profissão, pode, observadas as formalidades de que tratam o art. 971 e seus parágrafos, requerer inscrição no Registro das Empresas da respectiva sede, caso em que, depois de inscrito, ficará equiparado, para todos os efeitos, ao empresário sujeito a registro (art. 974);

Considera-se estabelecimento todo complexo de bens organizado, para exercício da empresa, por empresário, ou sociedade empresária (art. 1.142).

13. O Direito Agrário e o Direito Comercial. Chegados a esse ponto, parece inafastável a conclusão, que de há muito se vinha esboçando, de ser o Direito Agrário um Direito de Empresa, tal como o é o Direito Comercial ou Mercantil em sentido amplo. Assim a doutrina predominante como a legislação - quer já positivada, quer ainda projetada (e aqui o Projeto de Código Civil merece um realce todo especial) —, até mesmo a constitucional, corroboram o resultado que se alcançou. Tanto quanto o Direito Comercial ou Mercantil em sentido amplo, o Direito Agrário é um direito de exceções ao Direito Civil.

Mas, voltando à questão da identificação do Direito Agrário, se foi possível situá-lo perante o Direito Civil como um Direito de Empresa, resta ainda observá-lo juntamente como o Direito Comercial ou Mercantil em sentido amplo, isto é, falta responder à indagação: o Direito Agrário pertence ao campo do Direito Comercial stricto sensu, ou ao do Direito Industrial, ou compõe campo à parte? 
D. O Direito Agrário e o Direito Comercial lato sensu

\section{Paralelismo entre Direito Agrário e Direito Comercial. O Direito} Agrário e o Direito Comercial lato sensu apresentam entre si notáveis semelhanças, mormente no que concerne a serem direitos de exceções ao Direito Civil; sua trajetória histórico-dogmática entre nós também mostra, sobretudo a partir da Constituição de 1988, um interessante ponto comum. Vimos ${ }^{32}$ que, nos idos de 1850, a distinção entre o Direito Civil e o Direito Comercial se associava a duas questões principais: a. uma, de qualificação jurídica, dado que certos contratos e obrigações, se mercantis, se submeteriam à incidência e aplicação de normas jurídicas excepcionais, e não-comuns; e b. outra, de competência jurisdicional, em virtude da existência dos Tribunais de Comércio ao lado da Justiça Civil, duplicidade essa, porém, eliminada em 1875, com a unificação da Justiça Cível.

As questões que se apresentam como razões de uma eventual distinção entre o Direito Agrário e o Direito Civil são muito semelhantes. A partir de 1964, com o advento do Estatuto da Terra, surge no sistema jurídico do Direito Privado (cuja unidade nunca é demais proclamar) um novo problema de qualificação jurídica: certos contratos e obrigações passam a sujeitar-se à incidência e aplicação de normas jurídicas excepcionais, e não-comuns, tal como ocorre nos contratos e obrigações mercantis. É nomeadamente a hipótese dos contratos, e das obrigações deles decorrentes, de arrendamento rural (arts. 92-94 e 95 do Estatuto da Terra) e de parceria rural (arts. 92-94 e 96 do Estatuto da Terra), ambos vinculados à posse ou ao uso temporário da terra. De maneira análoga ao que dispõe o art. 121 do Código Comercial ("As regras e disposições do Direito Civil para os contratos em geral são aplicáveis aos contratos comerciais, com as modificações e restrições estabelecidas neste Código") estabelece o $\$ 9^{\circ}$ do art. 92 do Estatuto da Terra: "Para solução dos casos omissos na presente Lei, prevalecerá o disposto no Código Civil. Por outro lado, o caput do art. 126 da Constituição da República, na seção que trata dos tribunais e juízes dos Estados, introduz no âmbito da distinção entre o Direito Agrário e o Direito Civil o problema da competência, ${ }^{33}$ ao dispor que: "Para dirimir

\footnotetext{
32. Ver supra, n. 6.
}

33. Trata-se, no meu entender, de questão de competência de juízo. Sobre o tema, ver, por exemplo, Antônio Carlos de Araújo Cintra, Ada Pellegrini Grinover e Cândido Rangel Dinamarco Teoria Geral do Processo, $3^{\mathbf{a}}$ ed., ampliada e atualizada, São Paulo, Editora Revista dos Tribunais, 1981, pp. 194-203, especialmente pp. 200-201. 
conflitos fundiários, o Tribunal de Justiça designará juízes de entrância especial, com competência exclusiva para questões agrárias" (grifos meus).

Não-obstante a notável semelhança entre as díades "Direito Comercial - Direito Civil" e "Direito Agrário - Direito Civil" decorrente, no meu entender, de assim o Direito Comercial lato sensu como o Direito Agrário serem direitos de empresa, ${ }^{34}$ parece necessário distinguir o Direito Agrário do Direito Comercial lato sensu. Essa distinção não deve ser buscada apenas por exercício ou mero deleite intelectual, com o simples objetivo de proclamar a autonomia legislativa, científica, metodológica ou didática do Direito Agrário, senão deve decorrer do reconhecimento de que há razões político-jurídicas ou técnico-jurídicas que justifiquem ou imponham a diferenciação. ${ }^{35}$

15. "Terreno": terra (fator de produção) e base física. Se o Direito comercial lato sensu e o Direito Agrário são direitos de empresa, é justamente no âmbito da conceituação econômica da empresa, ou no âmbito da conceituação jurídica dos seus três termos (aspectos ou perfis) que se implicam e exigem dialeticamente, a saber, o empresário, a atividade empresarial e o estabelecimento empresarial, ${ }^{36}$ que podemos buscar algum critério distintivo.

Todavia, se doravante nosso trabalho se desenvolve no terreno eminentemente conceitual, visto que é a partir de certos conceitos (empresa, empresário, atividade empresarial e estabelecimento empresarial) que tentamos, mediante certas distinções, chegar a outros (Direito Comercial lato sensu e Direito Agrário), é fundamental salientar o caráter contingente e relativo dos conceitos, cujo valor é apenas instrumental. Não nos iludamos ao encarar os conceitos como entidades reais, gerais, universais, eternas e imutáveis, atribuindo-lhes valor absoluto e transcendente. Não: os conceitos são meras representações de realidades mutáveis, construídas - e não dadas a priori - pelo esforço intelectual, e, portanto, simples entidades intelectuais; a ciência busca os conceitos não como fins em si próprios, senão como instrumentos para a compreensão de uma realidade; assim, não são eles verdadeiros ou falsos, porém mais úteis ou menos úteis aos fins a que se destinam. Juridicamente, os conceitos são esquemas de compreensão e explicação da

34. Ver supra, ns. 8-13.

35. Ver supra, n. 10.

36. Ver supra, n. 5. 
Juridicamente, os conceitos são esquemas de compreensão e explicação da experiência jurídica, bem como instrumentos - e não causas geradoras - da aplicação do Direito, como prismas através dos quais passam os comandos gerais. ${ }^{37}$

Já vimos ${ }^{38}$ que ao Direito de Empresa corresponderiam as atividades de produção ou de circulação de bens ou serviços; tendo em vista a própria atividade empresarial, especificamente no tocante ao seu objetivo, o Direito de Empresa admitiria a seguinte subdivisão: a. Direito Comercial ou Mercantil em sentido estrito, se a atividade empresarial se destinasse à circulação de bens ou serviços; e b. Direito Industrial (que pertence tradicionalmente ao Direito Comercial ou Mercantil em sentido amplo), se a atividade empresarial visasse à produção de bens ou serviços. Vimos também ${ }^{39}$ que, no concernente ao resultado propriamente dito do exercício da atividade empresarial destinada à produção de bens ou serviços, poderíamos subdividi-la segundo a finalidade dos produtos: a. produtos para a alimentação; e b. outros produtos; contudo, a utilidade de tal distinção foi posta em dúvida por vários motivos. ${ }^{40}$ Seja como for, ainda nos resta buscar uma distinção entre o Direito Comercial ou Mercantil em sentido amplo e o Direito Agrário, procurando defini-los ou conceituá-los.

Tenho para mim que é possível introduzir no conceito econômico de empresa, ou, o que vem a dar no mesmo, nos conceitos de seus termos (aspectos ou perfis) que se implicam e exigem dialeticamente, a saber, o empresário, a atividade empresarial e o estabelecimento empresarial, algumas especificidades capazes de nos permitir uma distinção entre os vários direitos de empresa.

Retomando algo que já foi exposto, ${ }^{41}$ parece difícil alcançar um conceito jurídico único de empresa, sendo talvez mais apropriado falar de aspectos ou perfis jurídicos do conceito econômico de empresa: $1^{\circ}$ em sentido subjetivo, como expressão sinônima de empresário, substituindo-se, por metonímia, o agente pela atividade por ele exercida; $2^{\circ}$. em sentido funcional, como atividade empresarial dirigida a certo objetivo; $3^{\circ}$ em sentido objetivo e patrimonial, como complexo de

37. Fábio Konder Comparato - O poder de controle na sociedade anônima, cit., pp. 83-84, especialmente a nota 3 da p. 84.

38. Ver supra, n. 9.

39. Ver supra, n. 10.

40. Ver supra, n. 10.

41. Ver supra, n. 5. 
bens organizado pelo empresário para o exercício da atividade empresarial (estabelecimento); e $4^{\circ}$ em sentido corporativo, como instituição decorrente de uma organização de pessoas, formada pelo empresário, pelos prestadores de trabalho e seus colaboradores, visando a um objetivo econômico comum. Empresário, por sua vez, é quem exerce, profissionalmente, uma atividade econômica organizada para a produção de bens ou serviços; são, portanto, elementos do conceito de empresário: a. o exercício de atividade econômica, destinada à criação ou circulação de riquezas; b. a atividade organizada mediante adequada coordenação dos fatores de produção (terra, capital, trabalho e tecnologia); e c. o exercício praticado de modo profissional, isto é, habitual e sistemático. Ora, falar em atividade econômica organizada pressupõe um complexo de bens destinado a um objetivo de produção ou de circulação: atividade empresarial e estabelecimento são, portanto, noções complementares. E mais: a atividade econômica organizada pressupõe alguém que a exerça, organizadamente, isto é, a figura do empresário está implícita nas duas noções, surgindo, portanto, uma dialética de implicação e polaridade entre estes termos: empresário, atividade e estabelecimento.

Uma distinção possível entre o Direito Comercial em sentido estrito e o Direito Industrial já foi apontada, ${ }^{42}$ fundando-se numa diversidade de objetivo da atividade empresarial: naquele, a circulação de bens ou serviços, e, neste, a produção de bens ou serviços. Sendo a agricultura lato sensu atividade destinada à produção de certo tipo de bens, o Direito Agrário seria, além de um Direito de Empresa, um Direito Industrial.

Ora, a atividade econômica é organização, mediante a coordenação adequada, dos diversos fatores de produção, isto é, da terra, do capital, do trabalho e da tecnologia; e o estabelecimento empresarial é um complexo de bens destinado a um objetivo de produção ou de circulação. Da perspectiva da atividade econômica e do estabelecimento empresarial, parece-me que o "terreno" onde se situa uma fábrica apresenta função muito diferente da do "terreno" coberto por uma plantação: para a fábrica, o "terreno" é base física, que suporta as máquinas e as instalações (bens de capital) e, assim, como bem imóvel, é um dos componentes do estabelecimento; mas, para a plantação, o "terreno" é muito mais que base física: o "terreno" é terra - fator de produção —, e, como bem imóvel, é talvez o cerne, o núcleo, o componente essencial do estabelecimento. 
Este parece ser o único critério de distinção, político-jurídico e técnico-jurídico, entre empresas industriais e empresas agrárias: somente nestas a terra é fator de produção; naquelas não se há de falar em terra, senão em "terreno" mero suporte físico para o fator de produção capital (ou, mais rigorosamente, para uma parte do fator de produção capital). Mas isso não-implica afirmar que nas empresas agrárias devam estar ausentes os demais fatores de produção (capital, trabalho e tecnologia), senão que, além destes - presentes também nas empresas industriais —, há o outro (terra) — ausente nas empresas industriais. ${ }^{43}$

16. O Direito Agrário e o Direito (Civil) das Coisas. No que concerne à essencialidade do bem imóvel para o estabelecimento agrário, há pouco proclamada, cabe salientar que o tema é polêmico. Diz Pontes de Miranda:

Discute-se quanto à existência, ou não, de elemento que se possa considerar essencial ao fundo de empresa; noutros termos, se há elemento que, alienando-se os outros e não ele, não se tem por transferido o fundo de empresa; ou, alienado sem o terem sido os outros, se há de considerar transferido o fundo de empresa. Não há resposta a priori. Depende do gênero de comércio, indústria ou agricultura. ${ }^{44}$

Parece-me que, sendo a terra o fator de produção típico das empresas agrárias, mas só se podendo considerar juridicamente a terra como bem imóvel, é este - o bem imóvel, o fundus - o elemento essencial do estabelecimento agrário.

O caráter de essencialidade do bem imóvel para o estabelecimento agrário, vinculado à terra como um dos fatores de produção que se organizam, mediante adequada coordenação, por meio da atividade empresarial agrária, explica ainda uma diferença sensível entre o Direito Agrário e o Direito Comercial ou Mercantil lato sensu. Vimos ${ }^{45}$ que o Direito Comercial em sentido amplo é

\footnotetext{
43. Essa observação parece de grande importância, mormente diante da vacilação doutrinária em manter como agrária uma empresa em que a presença marcante de capital e de tecnologia conduz à afirmação (equivocada, no meu entender) de que se trata de empresa industrial.
}

44. Tratado de Direito Privado, cit., tomo XV, p. 371.

45. Ver supra, n. 6 
responsável pela introdução de uma normatividade excepcional (excepcional em relação ao Direito Civil, encarado como Direito comum) no tocante a certos contratos e obrigações; é, portanto, um direito de exceção ao direito obrigacional e contratual civil. ${ }^{46} \mathrm{O}$ Direito Agrário, por sua vez, não-obstante ser também um direito de exceção ao direito obrigacional contratual civil, parece-me predominantemente (conquanto não exclusivamente, ressalte-se) um direito de exceção ao Direito (Civil) das Coisas, em particular no que concerne ao Direito de Propriedade.

Não há dúvida de que o Direito Agrário introduz disciplina própria em certos tipos de contratos: o contrato de arrendamento rural, por exemplo, não deixa de ser um contrato de locação de bem imóvel, tipificado, porém, qualificadamente pela atividade empresarial nele desenvolvida, em que o "terreno" é terra - fator de produção; o contrato de parceria rural, por sua vez, não deixa de ser um contrato de sociedade, muito semelhante ao contrato de sociedade de capital e indústria, mas com tipicidade própria, em que o fator de produção trazido por um dos sócios não é capital, mas terra, cabendo ao outro o trabalho (indústria) e a própria atividade empresarial.

Mas tenho para mim que as exceções introduzidas pelo Direito Agrário no Direito Civil concernem precipuamente ao Direito das Coisas (mesmo os contratos de arrendamento e parceria rural têm por objeto, embora mediato, coisas - e coisas imóveis). As limitações ao Direito de Propriedade no que respeita aos imóveis rurais - já presentes nas obrigações decorrentes dos contratos de arrendamento e parceria rural - atingem graus incompatíveis com a noção comum (civil) da propriedade, em atenção ao que se costuma chamar função social da propriedade, especialmente no que concerne aos poderes de usar e dispor: o uso - e o uso qualificado mediante certos critérios de conveniência, oportunidade e eficiência - é, por assim dizer, imposto ao titular do domínio, sob pena de perda da propriedade por desapropriação; e o poder de disposição encontra óbices em eventuais direitos de preferência e principalmente na impossibilidade de subdivisão abaixo de uma certa extensão — o módulo rural. Mas não é só: um dos modos de aquisição da propriedade — o usucapião — passa a ter como hipótese de incidência uma facti species toda peculiar, em que a atividade ("tornando-o produtivo por seu trabalho" na expressão do art. 92 do Estatuto da Terra) supera o mero estado de fato 
("possuir como seu". nos termos do art. 550 do Código Civil), surgindo, assim, o chamado "usucapião pro labore" agora presente no texto constitucional (Constituição da República, art. 191, caput).

17. Direito Civil, Direito Comercial e Direito Agrário. Para remate e tentando uma síntese, todas essas observações parecem confirmar o critério distintivo ente o Direito Comercial ou Mercantil em sentido amplo e o Direito Agrário, atrás sugerido. ${ }^{47}$ Ambos colocam-se lado a lado perante o Direito Civil, como direitos de empresa; mas não se sobrepõem porque apenas na atividade empresarial agrária o "terreno" é terra — fator de produção —, sendo mero suporte físico de capital - fator de produção — na atividade comercial ou mercantil lato sensu.

São Paulo, janeiro de 1999. 